\title{
Bycatch levies could reconcile trade-offs between blue growth and biodiversity conservation
}

\author{
Hollie Booth ${ }^{1,2^{*}}$, William N. S. Arlidge ${ }^{1,3,4}$, Dale Squires ${ }^{5,6}$, EJ Milner-Gulland ${ }^{1}$
}

1. The Interdisciplinary Centre for Conservation Science (ICCS), Department of Zoology, University of Oxford, Oxford, UK

2. Wildlife Conservation Society, The Bronx, NY, USA

3. Faculty of Life Sciences, Albrecht Daniel Thaer Institute of Agricultural and Horticultural Sciences, Humboldt-Universität zu Berlin, Berlin, Germany

4. Leibniz-Institute for Freshwater Ecology and Inland Fisheries, Germany

5. Department of Economics, University of California San Diego, USA

6. Southwest Fisheries Science Centre, National Oceanic and Atmospheric Administration, San Diego, CA, USA

*Corresponding author: hollie.booth@zoo.ox.ac.uk

\section{Summary}

Economic activities in the ocean (i.e. the 'blue economy') provide value to society, yet also jeopardise marine ecosystems. For example, fisheries are an essential source of income and food security for billions of people, yet bycatch poses a major threat to marine biodiversity, creating trade-offs between economic growth and biodiversity conservation. This paper explores bycatch levies as a market-based instrument for reconciling these trade-offs. We outline the theory and practice of bycatch levies, to demonstrate how they could incentivise bycatch prevention and raise revenue for compensatory conservation, provided they are well-designed, as part of a policy mix for sustainable and equitable ocean governance. We then explore ways forward for mainstreaming bycatch levies in to the blue economy. While compensatory bycatch mitigation has been controversial, increasing adoption of net outcome approaches to biodiversity conservation suggests they could become mainstreamed within the next decade. Bycatch levies could raise millions of dollars towards closing global biodiversity financing gaps; delivering net outcomes for biodiversity under the UN Biodiversity post-2020 framework whilst enabling blue growth, and moving towards win-wins for economic welfare and biodiversity conservation.

Key words: incentives, marine conservation, payments for ecosystem services, market-based interventions, environmental levies, compensatory offsets, no net loss 
1 Ocean ecosystems support the well-being of billions of people [1], [2], and are projected to contribute

2 US \$3-trillion to the global economy by 2030 via 'blue growth' [3]. Blue growth aims to deliver economic

3 growth through exploitation of marine resources, while also preventing their degradation [4]. However,

4 there is a need to reconcile expectations for economic growth with biodiversity conservation [4], [5],

5 because economic activities in the ocean also inherently jeopardise marine ecosystems [2], [6], [7]. In

6 parallel to the blue growth agenda, the UN Convention on Biological Diversity (CBD) is developing a

7 post-2020 framework to "put biodiversity on a path to recovery" [8], [9]. Ambitious targets and an

8 integrated approach are needed to bend the curve on global biodiversity loss, while also delivering

9 improvements to human well-being [10]-[12]. As such, the CBD post-2020 framework is likely to include

10 'net outcome' goals, either explicitly or implicitly [9], [12], [13]. Net outcome goals imply that some

11 biodiversity may be lost, as long as it is gained elsewhere, resulting in an overall balance ("no net loss

12 (NNL)') or increase ('net gain') in biodiversity. Transformative change is needed to integrate net outcome

13 goals into fisheries management objectives, and thus establish profitable yet biodiversity-neutral (i.e.

$14 \geq \mathrm{NNL}$ ) fisheries within the coming decade.

Fisheries bycatch (defined here as incidental catch that is either "unused or unmanaged" [14]) poses a major threat to marine biodiversity [15], and is one of the most intractable challenges for reconciling blue growth with biodiversity conservation. Bycatch is costly to fishers and society, because it threatens biodiversity, ocean ecosystems and the viability of fisheries [14], [16]-[19]. However, mitigating bycatch is also costly to fishers and ocean managers, as it can be data intensive, require new or cumbersome technologies, and create opportunity and management costs [20]-[22]. In economic terms, bycatch is a negative externality, comparable to carbon emissions and air pollution [23], which occurs when an economic transaction by a private economic entity (e.g. a fishing firm) imposes a cost on society, which is unpriced or only partially priced by markets. As a result, the environmental costs of fishing to society exceeds the private cost of fishing to firms, and the market maximises private benefit for the firm, but not total benefit to society (i.e. social welfare, wherein economic welfare is a subset of social welfare, measured in monetary terms) (Figure 1).

A mix of instruments is needed to mitigate bycatch and restore bycatch-affected populations [24]. The main types of instruments that can be used fall into two broad categories: direct regulation and marketbased approaches (Figure 2). Direct regulations are implemented via command-and-control, while market-based approaches can be mandated through public policy (e.g. taxes) or adopted voluntarily (e.g. certification schemes). Intrinsic motivations and informal institutions, such as social norms, also offer a potential third category of instrument, which can interact with regulatory and market-based approaches. While we do not discuss intrinsic motivations in detail here, they can interact with other instrument-types both positively (via 'crowding in') and negatively (via 'crowding out'), and therefore warrant attention when designing an overall policy mix for a given situation [25]-[27]. 
39 Despite the range of available instruments, most bycatch mitigation measures focus on direct regulation, with mandated technical fixes such as gear specifications or catch bans. Such measures can be simple, easy to enforce and have low management costs; yet also inflexible, and can fail to deliver socially-optimal outcomes or incentives for behaviour change, when used in isolation (Figure 2) [21], [28]. As decisionmakers usher in the blue economy, there is growing discussion around market-based fisheries management (e.g. [29] [30]), and particularly the need to end harmful subsidies, which currently far outweigh conservation spending [29], [31]. However, incentive-based instruments for bycatch management, such as bycatch levies, have received comparatively little attention. While fisheries economists have explored the potential of bycatch levies for decades [22], [24], [32]-[35] there remain few real-world applications (See section 2.5). This represents a missed opportunity for closing the gap on marine conservation financing [36].

One possible reason for the limited application of bycatch levies is that they have yet to be deemed societally acceptable. Under the 'Polluter Pays Principle', bycatch levies require a willingness-to-accept (WTA) monetary compensation to society for damage to biodiversity [37]. This entails a utilitarian approach to valuing biodiversity, with consensus on permissible levels of bycatch and its monetary value, which remains controversial. For example, proposed compensatory offsets for seabird bycatch [34] were met with value-based concerns regarding costs to biodiversity and limits of permissible risk [38], [39]. Levies also require a willingness-to-pay (WTP) compensation amongst fishing firms. WTP may be limited in the absence of regulation or clear reputational risks/advantages, since levies are likely to reduce profit margins, particularly if price premiums cannot be secured from consumers [40], [41]. Securing WTP will be even more challenging (and arguably unethical) in small-scale fisheries, where profit margins are low; and in international/high-seas fisheries, where the right-holders are unclear or not formally recognised.

However, with growing adoption of net outcome approaches for biodiversity conservation more broadly [42], [43], and the need to close the global biodiversity financing gap [31], it is timely to re-visit the potential of bycatch levies in fisheries. Here we describe how well-managed bycatch levies could help to deliver net positive outcomes for marine biodiversity, alongside 'blue growth' (i.e. economic welfare outcomes) for society [44] (Figure 2), potentially leading to win-wins for blue growth and biodiversity. We explore key considerations for designing bycatch levies based on economic theory and real-world examples, and discuss next steps for mainstreaming bycatch levies into the blue economy.

\section{Bycatch levies for net biodiversity outcomes}

Mitigating bycatch requires changing the behaviour of fishing firms (i.e. individual fishers, vessels, fleets and companies) and consumers. This can be achieved through direct regulation or market-based interventions. Direct regulations typically mandate fixed standards on catch, bycatch, process, or 
technology, while market-based interventions create incentives for individual firms to alter their behaviour towards a societal optimum, allowing for individual behaviour change and innovation (Figure 2). The most basic type of market-based intervention for bycatch is a levy that sets a price on each unit of bycatch. Such levies can be established voluntarily or mandatorily, and provide a 'double dividend' through two types of benefits: first, by incentivising bycatch prevention; second, by raising revenues for compensatory conservation. These revenues can then be invested in improving the status of bycatchaffected populations, or financing socially-underprovided research and development for bycatchminimizing technologies [35], [45]. In principle, these two dividends can together deliver no net loss (NNL) or net gain outcomes for by-catch affected species (Figure 2); though with inevitable time lags, uncertainties and governance challenges for securing compensatory outcomes in practice [46]-[48].

\section{Designing bycatch levies for net biodiversity outcomes}

Bycatch levies are not a silver bullet for all types of market failure that exacerbate bycatch (e.g. weak property rights and asymmetries in power and information). Their scope is limited to addressing bycatch as a negative externality, by putting a marketable price on its external cost; and to situations where at least some of the actors causing bycatch issues are prepared to pay levies, and society is prepared to accept compensatory actions to recover lost biodiversity rather than requiring that bycatch is prevented entirely. Levies can be established through government regulation, such as mandatory bycatch taxes (e.g. New Zealand and Namibia's quota management systems, Section 2.5) [33]); or voluntarily, such as conservation payments as part of corporate social responsibility [49], [50] (e.g. the International Seafood Sustainability Foundation (ISSF), Section 2.5) [51], [52]. Though both mandatory and voluntary adoption of bycatch levies are limited at present, changes in environmental governance, investor expectations and wholesale and retail markets could drive expansions of marine biodiversity offset markets in the coming decade [53], and substantially increase the scope for levies to be implemented (see Section 4).

Moreover, the extent to which bycatch levies deliver each dividend, and therefore their pathway to conservation outcomes, depends on their design. Different design choices - including how to target, price and invest levies - have different pros and cons. As such, the optimal levy design choices depend on the fishery and socio-economic context (Table 1).

\subsection{Targeting levies}

A key design choice is setting the level of production for targeting the levy [50]; and relatedly, the outcome on which to base the levy [45], [49], [50]. Regarding level of production, a levy could be applied at an industry-wide scale (e.g. as a lump-sum, applied across all producers of a given species, nationally), a fleet-wide scale (e.g. applied to a particular sub-set of jointly-operating vessels, which fish in a specific seascape or use a certain bycatch-intensive technology) or vessel-specific. Regarding outcomes, the levy could be set according to fishing practices (i.e. process-based) or actual bycatch (i.e. performance-based) 
110 (Figure 3, Table 1) [45]. Different design choices will have different pathways to conservation impact, and 111 entail different trade-offs between incentives for behaviour change and uncertainty/management costs.

112 As such, the optimal design choice for targeting a levy depends on the fishery and management context 113 (Figure 3, Table 1).

In terms of the first dividend, a bycatch levy can incentivise firms to mitigate bycatch in two ways: 1) altering the bycatch-catch ratio, e.g. though behaviour change and technological innovation; or 2) altering the level of effort, which lowers both bycatch and catch. These two strategies are not equally feasible in all fisheries [22]; their feasibility depends on the relationship between target catch production and bycatch, in particular, the homogeneity and frequency of bycatch events [45]. Across different fisheries bycatch-catch ratios can range from homogenous and frequent, in which bycatch relates to inherent biophysical characteristics of the target and bycaught species, and is directly proportional to target catch (e.g. mako shark Isurus spp. bycatch in swordfish fisheries); to heterogenous and rare bycatch, in which bycatch is stochastic and unpredictable (e.g. leatherback sea turtle Dermochelys coriacea bycatch) [22], [45]. In the middle are situations where bycatch varies with broad-scale characteristics of the fishing process, such as fishing ground, gear and season, or with individual skipper skill (Figure 3, Table 1). These characteristics influence the possible mechanisms and costs of avoidance, where to target the levy, and therefore how it might lead to conservation impact. For example, if bycatch is homogenous and altering the bycatch-catch ratio is unfeasible in the short-term, a flat-rate industry-wide process levy could lead to some bycatch prevention by incentivising reductions in fishing effort, and could provide stable revenues for compensatory conservation. Conversely, if bycatch is heterogenous and avoidable, with possibilities for lowering the bycatch-catch ratio, an individually-targeted performance-based levy could impact fisher behaviour and decision-making at the margin, thus incentivising individual vessels to alter bycatch-catch ratios and/or the level of effort. If bycatch is stochastic, a standard fleet-level compensatory lump-sum may be appropriate, with fisher risk-pooling and insurance to smooth the financial risk and improve fishers' perceived fairness [54], [55] (Figure 3, Table 1).

Bycatch levy design choice also entails trade-offs between incentives for behaviour change, uncertainty/management costs and stability of compensatory revenues for conservation. The closer the link between the cost of the levy and bycatch performance, the stronger the incentive to alter the bycatch-

140 catch ratio; however management costs will be higher [45] and revenues for conservation via the second 141 dividend will vary. For example, in flat-rate process-based levies, such as all vessels paying a standard bycatch charge as part of their fishing permit, there will be stable revenues for conservation and lower monitoring uncertainty, since the cost of the levy is pre-determined and true bycatch performance is not measured. However, incentives for individual behaviour change at the margin will be limited, though this levy may drive short-term changes in fishing effort and long-term technological innovations to reduce target catch-bycatch ratios. Conversely, individually-targeted performance-based levies, such as a charge 
for each individual of a threatened species landed by a vessel, create stronger incentives for bycatch prevention through individual behaviour change. However, revenues for conservation will vary, and the degree of uncertainty faced by fishers and managers will be higher. There will also be information asymmetries and higher transaction costs to the management authority, with a need for robust monitoring (such as human or electronic fisheries monitors) to measure bycatch performance and ensure compliance (Table 1). One option for reducing costs to managers is setting standard rates or advanced payment based on an expected mean value of bycatch (e.g. according to past observer data), with performance-based rebates which place the burden of proof on to the firms themselves [54]. There is also potential to leverage cooperation and competition between firms, to improve monitoring and performance via peermonitoring and group-level incentives [56], [57]. The degree to which group effects can promote effective and efficient outcomes will vary across different levy designs, fleet-types, and socio-economic contexts (Table 1), as per transactions and information costs, social networks and institutions, and the costs and benefits of cooperation [57]-[59].

Regardless of the model, least-cost NNL is achievable in all cases [52], primarily through prevention in individually-targeted performance-based levies, and compensation in flat-rate process-based levies (Table 1). In the long-run, the second dividend may erode as firms shift to better practices and lower bycatchcatch ratios (where technologically feasible), with the first dividend becoming the dominant pathway to NNL. This is lower risk from a biodiversity impact perspective, but requires that any conservation actions which are funded by compensatory offsets are future-proofed, either by ensuring that compensatory investments are transitional from the outset (e.g. to cover transition to a new technology or practice), or securing new sources of income as the second dividend erodes.

\subsection{Pricing levies}

A socially-optimal levy price is one at which the marginal private cost of bycatch prevention is equal to its marginal social benefit [44], [52]. However, calculating optimal prices is often unfeasible [60], particularly given challenges surrounding valuing biodiversity [61]. Rather, measuring marginal or average costs and improving cost-effectiveness may be more realistic, where the costs of different bycatch mitigation approaches are assessed and compared [44], [52], [62], [63]. One option is setting prices based on the average costs of compensatory conservation, such as habitat protection [44], invasive species eradication [34], [64], [65], or bycatch reduction technologies (BRTs) and payments for ecosystem services in smallscale fisheries [30]. Alternatively, societal values for bycaught species could be inferred using benefit transfer methods, based on tourist expenditures or public willingness-to-pay surveys [66]-[69].

For example, in the Hawaii swordfish longline fishery, it is estimated that an average of 0.01 leatherback turtles are taken as bycatch per thousand hooks (2004-2012) [70], while the average annual cost of leatherback turtle nesting habitat conservation is US $\$ 1,558$ per adult female leatherback [44]. As such, a 
process-based levy of US $\$ 15.58$ per thousand hooks, or a performance-based levy of US $\$ 1,558$ per bycaught individual could be applied. In the Eastern pacific tuna purse seine fishery, bycatch mortality of mobulid rays is estimated at 0.16 mobulid rays per set on average [71]. As a proxy societal value, an individual mobulid ray is worth up to US\$1,620 per individual per year in the Maldives dive industry. In this case, a fleet-wide tax of US $\$ 259.2$ per set could be applied, or, at an estimated 200 sets per trip, a vessel could be required to purchase US $\$ 51,800$ in bycatch quota before being allowed to fish, with posttrip rebates for good performance [72]. However, such figures may under- or over-estimate sociallyoptimal rates, e.g. by failing to account for the opportunity costs of bycatch reduction or for intangible, indirect (e.g. via ecosystem processes), diffuse and shared values of the species concerned to society [73], [74]. For example, US $\$ 51,800$ per trip may be a prohibitively large sum, which no purse seine vessels are willing or able to pay, resulting in fishers being unable to conduct any fishing trip, and a loss of this fishery value to society. Conversely, the Maldives dive industry figures may underestimate the societal value of mobulids. For example, US $\$ 1,620$ is based on an annual tourism value per individual, rather than the value of an animal over its entire lifetime, which may be as high as US\$1-million [68]. Societal values are also likely to shift as species recover or become rarer, or as technology changes. Thus, adaptive management will be needed to update pricing over time. Levy rates could also account for extinction risk and monitoring uncertainty via risk premiums. For example, if a species' population size is low, the severity of a single bycatch event is high, warranting a risk multiplier. This could allow weighting of levies according to species endangerment, which may be important for non-charismatic bycatch-affected species (e.g. wedgefish (Rhinidae spp.) and short-nosed sea snakes (Aipysurus apraefrontalis)), which require management but may have limited tangible value in economic welfare terms. Possible substitution or displacement effects also warrant consideration to avoid unintended cross-taxa conflicts: levy pricing should be designed holistically, considering all by-catch affected species within a given fishery [75]. Rates could also increase with mortality per trip/vessel, as per New Zealand's deemed-value quota management model [33] (Section 2.5). Multipliers could also be applied to account for monitoring and offsetting uncertainty, with precautionary multipliers identified as a key determinant for successful NNL outcomes in terrestrial offsetting [46], [47]. Where uncertainty also increases management costs, these costs could be included as part of the pricing (though should not be so

Finally, equity and fairness should be considered when setting prices, since market-based interventions can have mixed impacts on social welfare and distribution [76], [77]. Issues include distributional impacts on fishers who will be directly affected by the levy, as well as wider societal impacts on downstream seafood consumers and beneficiaries. For example, bycatch levies may be unfeasible and unethical in small-scale fisheries (SSFs) in the Global South, where there is limited capacity to collect levies, and limited resource and adaptive capacity to pay or change behaviour [1], [78]. Rather, a progressive 
approach could support distributive justice, with levies paid by larger-scale commercial fisheries or downstream high-end consumers, and invested in bycatch mitigation in SSFs. For example, in the US California drift gillnet fishery, a voluntary turtle bycatch levy funded sea turtle bycatch mitigation in Mexican SSFs [51] (Section 2.5). In-kind payments, such as volunteering time towards species restoration, may also be feasible in SSFs [79], while bank-backed insurance schemes can help to smooth financial risks where individual vessels cannot cover costs of rare, stochastic bycatch events [54], [55]. Fairness can be improved by adopting open and inclusive processes for designing levies, which facilitate process justice. This can ensure rights for all participants, identify distributional concerns, and also help to improve uptake and compliance through building legitimacy [80], [81].

\subsection{Investing revenues}

Potential beneficiaries of levy revenues are those who can safeguard or restore bycatch-affected populations, including fishers and those who have property rights (i.e. legal or de facto control or ownership) over critical habitat or bycatch-affected populations. Revenues could be distributed over multiple scales (Table 2). For example, levies could be fiscally-neutral at fishery or national levels, with poorly-performing firms paying penalties, and well-performing firms receiving incentives. This could be suitable when bycatch is heterogenous within or across fleets, by incentivising technological innovation within fleets, or discouraging the most bycatch-intensive technologies. Alternatively, revenues could be distributed internationally, with wealthy countries investing in habitat conservation, technological change, and performance-based catch mitigation elsewhere [32], [82] (Table 2). This can also contribute to greater equity, with revenues from larger commercial fleets financing improvements in low-income SSFs. Intertemporal equity could also be accounted for by wealthy nations with historically large fisheries impacts committing to net gains for marine biodiversity under the CBD’s post-2020 framework [83], and by considering future generations' preferences for biodiversity (i.e. accounting for inter-generational equity).

\subsection{Monitoring, compliance and adaptive management}

Conditionality and additionality are key features of incentive-based approaches. Conditionality requires that incentives are contingent on verifiable performance, and additionality requires that an action would not have occurred otherwise. Therefore, robust monitoring and compliance management are essential. This is challenging in fisheries, due to high monitoring costs for marine biodiversity and fisheries [84][86]. Since there are trade-offs between incentives and management costs (Table 1) [45], monitoring and enforcement capacity should be considered in the design phase. For fisheries with high compliance and observer coverage, performance-based levies may be more feasible, whereas process-based levies which can be determined through third-party monitoring (e.g. GlobalFishingWatch) may be more appropriate under poor observer coverage. Advances in satellite monitoring, electronic on-vessel monitoring and machine learning will reduce costs and uncertainties in bycatch monitoring in the coming decade [87], [88]. Furthermore, advances in DNA metabarcoding can also enable forensic monitoring, e.g. using 
eDNA to reconstruct catch through hold sampling [89]-[91]. In the interim, peer-monitoring and placing the burden of proof on firms could reduce monitoring costs.

Monitoring and enforcement are also important when investing revenues, to prevent leakage (i.e. where securing biodiversity in one location leads to the loss or degradation of biodiversity elsewhere), and ensure additionality, equivalence and permanence of biodiversity gains [46], [77]. Projects will require good governance and third-party monitoring and verification to ensure that these conditions are met and positive outcomes for biodiversity are delivered [48].

Importantly, we found little evidence of impact assessment or adaptive management in real-world applications of bycatch levies (Section 2.5). Data on fisher behaviour, bycatch mortality and the status of bycatch-affected populations are needed to inform adaptive management and understand if and how bycatch levies can deliver $>$ NNL. Socio-economic impacts of bycatch levies on affected people and downstream users also need to be understood, to prevent perverse social outcomes [76]. This could allow for adaptive management of levy designs, to ensure they are effective, progressive, and deliver $>$ NNL for people and biodiversity [92].

\subsection{Levies as part of a policy mix}

Finally, it is important to consider by bycatch levies as part of an overall policy mix, which can be used in conjunction with complementary instruments (as opposed to an 'either-or' dichotomy) [77]. For example, governments may wish to mandate the use of certain BRTs, while also using bycatch levies to incentivise additional reductions in mortality, or provide compensation for residual mortality over and above that which can be reduced through BRTs. This may be particularly important for highly-threatened and/or low-fecundity species, where compensatory mitigation strategies can be particularly risky [38]. For such species, bycatch levies could be used as the final step in a precautionary mitigation hierarchy of actions, where avoidance, minimisation and remediation measures (such as time-area closures and input standards) are mandated, and bycatch levies are used to further incentivise their adoption and compensate for residual unavoidable mortality [52], [62], [79], [93]. Similarly, other market-based mechanisms, such as performance-based incentives, can be used in conjunction with bycatch levies, e.g. with levy revenues reinvested in subsidizing socially-underprovided bycatch-minimizing technologies [45] (Table 3). However, in fisheries in which intrinsic motivation (e.g. social norms) is central to management, care must be exercised such that bycatch levies do not "crowd out" social norms [27]. On the other hand, regulations, incentives and intrinsic motivations can work synergistically in some situations, with the right policy mix helping to drive large-scale behavioural tipping points [25]. 


\subsection{Real-world examples}

294 To our knowledge, there are few real-world examples where bycatch levies have been implemented in 295 fisheries (Table 3). In Namibia, a mandatory bycatch fee is applied to prevent fishers from targeting 296 species they do not have quota for, which is set at a rate that is higher than the quota fee. In 2012/3, over 297 NAD 6 million ( US $\$ 400,000$ ) was levied in bycatch fees, representing $4.5 \%$ of total government 298 revenues from fisheries that year [33], [94]. In the USA, there are two examples of process-based voluntary levies, which have been paid by groups of swordfish and tuna fishers, as compensatory funding for sea turtle conservation in nesting habitats and small-scale fishers [37], [51], [82]. These levies do not provide incentives for individual behaviour change at the margin, though do create incentives for broader-scale effects on fishing effort. It is also estimated that they support significantly more turtle conservation per dollar cost than at-sea prevention measures [44], [52]. In New Zealand, a 'deemed value' is used to reduce management-induced discards (i.e. discards of over-quota catches). In this system, a mandatory performance-based charge is levied against landings for which fishers do not have sufficient quota. The deemed value rates are set to disincentivise discarding at sea, while not incentivising targeting of fish for which the fishers do not have quotas: fishers are allowed to land and sell over-quota catch, but pay a fee per kilogram, which varies by stock and increases with amount caught in excess of quota [33], [95], [96].

Aside from these real-world applications, the hypothetical benefits of bycatch levies have been explored and quantified for turtles, marine mammals and seabirds in several case studies [34], [44], [54], [97], [98]. Various models predicting the impacts of bycatch levies on fisher behaviour and discards in general have also been developed [99]-[102].

To our knowledge, the social and biological impacts of these real-world examples have not been assessed. However, early examples from terrestrial offsetting indicate that such policies can incentivise prevention of environmental damage, and deliver positive ecological outcomes, provided there are appropriate risk premiums, and good governance to ensure compensatory conservation outcomes [47], [48], [103]. In the future, it will be important to understand how fisher behaviour, bycatch-affected species, and welfare and distribution have been impacted by different types of levies, to learn lessons for future applications. 
 \\ 3. Mainstreaming bycatch levies into the blue economy}

We have examined the potential role of bycatch levies in delivering net outcomes for marine biodiversity, and the pros and cons of different design choices. If well-designed, and implemented either voluntarily or mandatorily as part of an overall policy mix, bycatch levies could be a useful instrument for incentivising bycatch mitigation during at-sea fishing operations and generating revenues for compensatory conservation. However, mainstreaming and uptake of bycatch levies remains dependent on securing firms' willingness-to-pay (WTP) levies and society's willingness-to-accept (WTA) compensation. This also requires broader acceptance of the Polluter Pays Principle in fisheries, and co-design of bycatch levies and offsets which are feasible, socially-acceptable and suited to context.

Since biodiversity offsets are increasingly mandated by governments and investors for terrestrial and coastal developments [42], [43], it is perhaps only a matter of time until compliance markets for bycatch levies and offsets also develop. Governmental implementation of bycatch levies could also be further stimulated via a net outcome approach to the CBD post-2020 framework [9], [13]. In the interim, voluntary WTP could be instigated through several avenues. Transparency and advocacy initiatives, to educate consumers and the public about bycatch issues, may increase firms' reputational risks of not addressing bycatch [105], [106], thus creating a 'strategic threat' as an incentive for voluntary participation [49]. This could also create tipping points for social change, wherein intrinsic motivations drive virtuous cycles of pro-conservation behaviour amongst fishing firms and seafood consumers [25]. For firms which are already under significant pressure to reduce bycatch, and may face high opportunity costs of direct regulation, such as complete fishery closures (e.g. the New England lobster pot fishery, which is under high public scrutiny due to whale entanglements [107]), adopting levies and investing in offsets could improve firms' reputations and allow them to continue operating [37], [51]. In turn, this could increase profits, economic welfare and revenues for compensatory conservation through levies on the additional economic surplus that is created. Bycatch levies could also create opportunities for improved access to investors, market share and prices (e.g. via eco-labels, exploiting WTP among seafood consumers), and thus positive incentives for voluntary participation. For example, seafood certification and corporate ocean stewardship schemes could introduce NNL or net gain policies as part of their standards; while the financial sector offers leverage points though growing investor expectations regarding sustainability [108], [109]. Just as investors and consumers are demanding "deforestation-free" terrestrial supply chains [110], [111], so they could demand "bycatch-neutral" fish supply chains. Given that just thirteen transnational companies control $19-40 \%$ of the largest and most valuable fish stocks [112], adoption of voluntary bycatch levies by a coalition of 'keystone actors' could raise substantial revenue for marine conservation. For example, the end value of the 7 most commercially-important tuna species is estimated at $\$ 42$ billion [113]. If bycatch levies were valued at $12 \%$ of this figure, they could raise enough finance to effectively 
protect $20-30 \%$ of the world's oceans, with additional long-term private and social gains from improved

358 fisheries, tourism and ecosystem services [114].

360 For bycatch levies to deliver net positive outcomes, a supply of investment-ready marine conservation projects is needed to deliver measurable and additional catch mitigation or population increases for a given US\$ investment. This is so that conservation gains to the bycaught species can be quantitatively balanced against the losses caused by bycatch, as per biodiversity offsets in terrestrial systems [46], [53]. However, there are few examples of such schemes, and the cost-effectiveness of marine conservation activities, in terms of biodiversity saved per dollar spent, is poorly understood. NGOs and governments could help to supply projects, in partnership with local communities, though they must be able to demonstrate additional conservation impacts and quantify the costs involved [30], [46], [115]. For marine biodiversity markets to develop at scale, third-party certification may be required, with intermediaries matching revenues with beneficiary projects, and external auditing to ensure funds are appropriately invested (e.g. as per lessons from conservation trust funds and REDD+ [116]-[118]). Further development of low-cost third-party methods for monitoring and verifying bycatch performance in fisheries (e.g. video monitoring, satellite monitoring and eDNA) and outcomes of marine conservation projects will be needed to reduce uncertainties and management costs in the future [30].

In sum, if well-designed and successfully mainstreamed, wide adoption of bycatch levies could move fisheries towards more socially-optimal outcomes for people and nature, by incentivising bycatch prevention, raising substantial revenue for conservation, and enhancing economic welfare. If paired with effective, additional marine biodiversity offsetting, this could help governments, companies and individuals contribute towards NNL or net gain goals for biodiversity under the CBD's post-2020

380 framework, and transform current trade-offs between fisheries and conservation into win-wins for blue growth and biodiversity. 


\section{Acknowledgments}

383 HB is grateful to the Oxford-NaturalMotion graduate scholarship for funding her DPhil studies, and to

384 Tom Pienkowski, Rodrigo Oyanedel and Sophus zu Ermgassen for reading and commenting on an early 385 draft of this manuscript. HB, WA and EJMG are grateful to The Pew Charitable Trusts, who have 386 supported this work through a Pew Marine Fellowship to EJMG. WA acknowledges support from the 387 US National Ocean and Atmospheric Administration, National Marine Fisheries Service, Southwest 388 Fisheries Science Center, the OX/BER Research Partnership Seed Funding (OXBER_STEM7) and the 389 Leibniz-Institute of Freshwater Ecology \& Inland Fisheries (IGB) 2020 short-term visit programme for 390 postdocs. This manuscript does not necessarily reflect the policy of US NOAA Fisheries.

\section{Author contributions}

392 HB conceptualised the paper, and led on writing and subsequent revisions of the original draft. WA, DS 393 and EJMG provided substantial inputs, guidance and mentorship throughout, in particular supporting 394 supervision, review and editing.

\section{Declaration of interests}

396 The authors declare no competing interests. 


\section{References}

[1] C. D. Golden et al., "Nutrition: Fall in fish catch threatens human health," Nat News, vol. 534, no. 7607, p. 317, 2016.

[2] B. S. Halpern et al., "Spatial and temporal changes in cumulative human impacts on the world's ocean," Nat Commun, vol. 6, no. 1, pp. 1-7, Jul. 2015.

[3] OECD, The Ocean Economy in 2030. OECD, 2016.

[4] W. J. Boonstra, M. Valman, and E. Björkvik, "A sea of many colours - How relevant is Blue Growth for capture fisheries in the Global North, and vice versa?," Mar Policy, vol. 87, no. September 2017, pp. 340-349, 2018.

[5] N. J. Bennett et al., "Towards a sustainable and equitable blue economy," Nature Sustainability, vol. 2, no. 11. Nature Publishing Group, pp. 991-993, 01-Nov-2019.

[6] K. L. Nash et al., "Planetary boundaries for a blue planet," Nat Ecol Evol, 2017.

[7] S. M. Maxwell et al., "Cumulative human impacts on marine predators," Nat Commun, vol. 4, no. 1, pp. 1-9, Oct. 2013.

[8] CBD, “Zero Draft of post-2020 biodiversity framework,” 2020.

[9] CBD, “UPDATE OF THE ZERO DRAFT OF THE POST-2020 GLOBAL BIODIVERSITY FRAMEWORK," Kunming, China, 2020.

[10] G. M. Mace et al., "Aiming higher to bend the curve of biodiversity loss," Nature Sustainability, vol. 1, no. 9. Nature Publishing Group, pp. 448-451, 01-Sep-2018.

[11] D. Leclere et al., "Bending the curve of terrestrial biodiversity needs an integrated strategy," Nature, vol. 2018, no. October 2018, pp. 1-6, Sep. 2020.

[12] J. W. Bull et al., "Net positive outcomes for nature," Nat Ecol Evol, vol. 4, no. 1, pp. 4-7, 2020.

[13] E. J. Milner-Gulland et al., "Four Steps for the Earth: mainstreaming the post-2020 Global Biodiversity Framework," One Earth, vol. 2050, pp. 75-87, 2020.

[14] R. W. D. Davies, S. J. J. Cripps, A. Nickson, and G. Porter, "Defining and estimating global marine fisheries bycatch," Mar Policy, vol. 33, no. 4, pp. 661-672, Jul. 2009.

[15] M. A. Hall, D. L. Alverson, and K. I. Metuzals, "By-Catch: Problems and Solutions," Mar Pollut Bull, vol. 41, no. 1-6, pp. 204-219, Jan. 2000.

[16] L. B. Crowder and S. A. Murawski, "Fisheries Bycatch: Implications for Management," Fisheries, vol. 23, no. 6, pp. 8-17, Jun. 1998.

[17] T. A. Branch, K. Rutherford, and R. Hilborn, "Replacing trip limits with individual transferable quotas: Implications for discarding," Mar Policy, vol. 30, no. 3, pp. 281-292, May 2006.

[18] R. L. Lewison, L. B. Crowder, A. J. Read, and S. A. Freeman, "Understanding impacts of fisheries bycatch on marine megafauna," vol. 19, no. 11, pp. 598-604, Nov. 2004.

[19] E. Gilman, D. Kobayashi, T. Swenarton, N. Brothers, P. Dalzell, and I. Kinan-Kelly, "Reducing sea turtle interactions in the Hawaii-based longline swordfish fishery," Biol Conserv, vol. 139, no. $1-$ 2, pp. 19-28, Sep. 2007. 
[20] J. T. Watson, T. E. Essington, C. E. Lennert-Cody, and M. A. Hall, "Trade-Offs in the Design of Fishery Closures: Management of Silky Shark Bycatch in the Eastern Pacific Ocean Tuna Fishery," Conserv Biol, vol. 23, no. 3, pp. 626-635, Jun. 2009.

[21] L. M. Campbell and M. L. Cornwell, "Human dimensions of bycatch reduction technology: Current assumptions and directions for future research," Endanger Species Res, vol. 5, no. 2-3, pp. 325-334, 2008.

[22] M. A. Hall, "On bycatches," Rev Fish Biol Fish, vol. 6, no. 3, pp. 319-352, Sep. 1996.

[23] V. L. Smith, "On Models of Commercial Fishing," 1969.

[24] J. Innes, S. Pascoe, C. Wilcox, S. Jennings, and S. Paredes, "Mitigating undesirable impacts in the marine environment: a review of market-based management measures," Front Mar Sci, vol. 2, no. OCT, p. 76, Oct. 2015.

[25] K. Nyborg et al., "Social norms as solutions," Science (80-), vol. 354, no. 6308, pp. 42-43, 2016.

[26] S. Bowles and S. Polanía-Reyes, "Economic Incentives and Social Preferences: Substitutes or Complements?," J Econ Lit 2012, vol. 50, no. 2, pp. 368-425, 2012.

[27] U. Gneezy, S. Meier, and P. Rey-Biel, "When and Why Incentives (Don't) Work to Modify Behavior," J Econ Perspect, vol. 25, no. 4, pp. 191-210, 2011.

[28] E. A. Fulton, A. D. M. Smith, D. C. Smith, and I. E. Van Putten, "Human behaviour: the key source of uncertainty in fisheries management," Fish Fish, vol. 12, pp. 2-17, 2011.

[29] U. R. Sumaila, V. Lam, F. Le Manach, W. Swartz, and D. Pauly, "Global fisheries subsidies: An updated estimate," Mar Policy, vol. 69, pp. 189-193, Jul. 2016.

[30] A. J. Bladon, K. M. Short, E. Y. Mohammed, and E. J. Milner-Gulland, "Payments for ecosystem services in developing world fisheries," Fish Fish, vol. 17, no. 3, pp. 839-859, Sep. 2016.

[31] A. Deutza et al., "Financing Nature: Closing the Global Biodiversity Financing Gap," 2020.

[32] P. H. Dutton and D. Squires, "Reconciling Biodiversity with Fishing: A Holistic Strategy for Pacific Sea Turtle Recovery," Ocean Dev Int Law, vol. 39, no. 2, pp. 200-222, May 2008.

[33] S. Pascoe et al., "Use of Incentive-Based Management Systems to Limit Bycatch and Discarding," Int Rev Environ Resour Econ, vol. 4, pp. 123-161, 2010.

[34] C. Wilcox and C. J. Donlan, "Compensatory mitigation as a solution to fisheries bycatchbiodiversity conservation conflicts," Front Ecol Environ, vol. 5, no. 6, pp. 325-331, Aug. 2007.

[35] P. H. Dutton and D. Squires, "Chapter 3. A Holistic Strategy for Pacific Sea Turtle Conservation," in Conservation of Pacific Sea Turtles, P. H. Dutton, D. Squires, and M. Ahmed, Eds. University of Hawaii Press, 2011, pp. 37-59.

[36] U. Rashid Sumaila et al., "Ocean Finance: Financing the Transition to a Sustainable Ocean Economy," Washington, DC, USA, 2020.

[37] D. Squires, V. Restrepo, S. Garcia, and P. Dutton, "Fisheries bycatch reduction within the leastcost biodiversity mitigation hierarchy: Conservatory offsets with an application to sea turtles," Mar Policy, vol. 93, pp. 55-61, 2018. 
[38] M. Finkelstein et al., "Evaluating the Potential Effectiveness of Compensatory Mitigation Strategies for Marine Bycatch,” PLoS One, vol. 3, no. 6, p. e2480, Jun. 2008.

[39] R. ŽYDELIS, B. P. WALLACE, E. L. GILMAN, and T. B. WERNER, "Conservation of Marine Megafauna through Minimization of Fisheries Bycatch," Conserv Biol, vol. 23, no. 3, pp. 608-616, Jun. 2009.

[40] J. Blomquist, V. Bartolino, and S. Waldo, "Price Premiums for Providing Eco-labelled Seafood: Evidence from MSC-certified Cod in Sweden," J Agric Econ, vol. 66, no. 3, pp. 690-704, Sep. 2015.

[41] C. A. Roheim, S. R. Bush, F. Asche, J. N. Sanchirico, and H. Uchida, "Evolution and future of the sustainable seafood market," Nat Sustain, vol. 1, no. 8, pp. 392-398, 2018.

[42] N. Shumway, J. E. M. Watson, M. I. Saunders, and M. Maron, "The Risks and Opportunities of Translating Terrestrial Biodiversity Offsets to the Marine Realm," Bioscience, vol. 68, no. 2, pp. 125-133, 2018.

[43] J. W. Bull and N. Strange, "The global extent of biodiversity offset implementation under no net loss policies," Nat Sustain, vol. 1, no. 12, pp. 790-798, 2018.

[44] H. Gjertsen, D. Squires, P. H. Dutton, and T. Eguchi, "Cost-Effectiveness of Alternative Conservation Strategies with Application to the Pacific Leatherback Turtle," Conserv Biol, vol. 28, no. 1, pp. 140-149, Feb. 2014.

[45] K. Segerson, "Chapter 19. Policies to Reduce Stochastic Sea Turtle Bycatch," in Conservation of Pacific Sea Turtles, P. H. Dutton, D. Squires, and M. Ahmed, Eds. Honolulu, HI: University of Hawaii Press, 2011, pp. 370-395.

[46] J. W. Bull, K. B. Suttle, A. Gordon, N. J. Singh, and E. J. Milner-Gulland, "Biodiversity offsets in theory and practice," Oryx, vol. 47, no. 3, pp. 369-380, Jul. 2013.

[47] S. O. S. E. zu Ermgassen, J. Baker, R. A. Griffiths, N. Strange, M. J. Struebig, and J. W. Bull, "The ecological outcomes of biodiversity offsets under 'no net loss' policies: A global review," Conserv Lett, no. April, pp. 1-17, 2019.

[48] S. O. S. E. zu Ermgassen, S. Marsh, K. Ryland, E. Church, R. Marsh, and Joseph W. Bull, "Exploring the ecological outcomes of mandatory Biodiversity Net Gain using evidence from early-adopter jurisdictions in England," SocArXiv, 2021.

[49] K. Segerson, "Voluntary approaches to environmental protection and resource management," Anпu Rev Resour Econ, vol. 5, pp. 161-180, 2013.

[50] M. J. Kotchen, "Voluntary-and information-based approaches to environmental management: A public economics perspective,” Rev Environ Econ Policy, vol. 7, no. 2, pp. 276-295, 2013.

[51] C. Janisse, D. Squires, J. A. Seminoff, and P. H. Dutton, "Conservation Investments and Mitigation: The California Drift Gillnet Fishery and Pacific Sea Turtles," in Handbook of Marine Fisheries Conservation and Management, Q. Grafton, R. Hilborn, M. Tait, and D. Squires, Eds. Oxford University Press, 2010, pp. 231-240. 
[52] D. Squires and S. Garcia, "The least-cost biodiversity impact mitigation hierarchy with a focus on marine fisheries and bycatch issues," Conserv Biol, vol. 32, no. 5, pp. 989-997, Oct. 2018.

[53] C. Jacob, J. W. van Bochove, S. Livingstone, T. White, J. Pilgrim, and L. Bennun, "Marine biodiversity offsets: Pragmatic approaches toward better conservation outcomes," Conserv Lett, vol. 13, no. 3, pp. 1-12, 2020.

[54] R. Lent and D. Squires, "Reducing marine mammal bycatch in global fisheries: An economics approach," 2017.

[55] R. Zhou and K. Segerson, "Individual vs. Collective Approaches to Fisheries Management," Marine Resource Economics, vol. 31, no. 2. MRE Foundation, pp. 165-192, 01-Apr-2016.

[56] N. Yagi, M. L. Clark, L. G. Anderson, R. Arnason, and R. Metzner, “Applicability of Individual Transferable Quotas (ITQs) in Japanese fisheries: A comparison of rights-based fisheries management in Iceland, Japan, and United States," Mar Policy, vol. 36, no. 1, pp. 241-245, 2012.

[57] M. J. Kotchen and K. Segerson, "On the use of group performance and rights for environmental protection and resource management," Proc Natl Acad Sci US A, vol. 116, no. 12, pp. 5285-5292, 2019.

[58] A. J. Stewart and J. B. Plotkin, "Collapse of cooperation in evolving games," PNAS, vol. 111, no. 49, pp. 17558-17563, 2014.

[59] A. Mani, I. Rahwan, and A. Pentland, "Inducing Peer Pressure to Promote Cooperation," Sci Rep, vol. 3, no. 1, p. 1735, Dec. 2013.

[60] T. Kroeger, "The quest for the 'optimal' payment for environmental services program: Ambition meets reality, with useful lessons," For Policy Econ, vol. 37, pp. 65-74, 2013.

[61] L. Ledoux and R. K. Turner, "Valuing ocean and coastal resources: A review of practical examples and issues for further action," in Ocean and Coastal Management, 2002, vol. 45, no. 9-10, pp. 583616.

[62] H. Booth, D. Squires, and E. J. Milner-Gulland, "The mitigation hierarchy for sharks : A riskbased framework for reconciling trade-offs between shark conservation and fisheries objectives," no. November, pp. 1-21, 2019.

[63] J. W. Bull and E. Milner-Gulland, "Choosing prevention or cure when mitigating biodiversity loss: Trade-offs under 'no net loss' policies," J Appl Ecol, vol. 57, no. 2, pp. 354-366, Feb. 2020.

[64] D. A. Norton and B. Warburton, "The potential for biodiversity offsetting to fund effective invasive species control," Conserv Biol, vol. 29, no. 1, pp. 5-11, Feb. 2015.

[65] N. D. Holmes, G. R. Howald, A. S. Wegmann, C. J. Donlan, M. Finkelstein, and B. Keitt, “The potential for biodiversity offsetting to fund invasive species eradications on islands," Conserv Biol, vol. 30, no. 2, pp. 425-427, Apr. 2016.

[66] A. J. Gallagher and N. Hammerschlag, "Global shark currency: The distribution frequency and economic value of shark ecotourism," Curr Issues Tour, vol. 14, no. 8, pp. 797-812, 2011.

[67] P. L. K. Mustika, M. Ichsan, and H. Booth, "The Economic Value of Shark and Ray Tourism in 
Indonesia and Its Role in Delivering Conservation Outcomes," Front Mar Sci, vol. 7, p. 261, Apr. 2020.

[68] M. P. O’Malley, K. Lee-Brooks, and H. B. Medd, “The Global Economic Impact of Manta Ray Watching Tourism," PLoS One, vol. 8, no. 5, 2013.

[69] G. M. S. Vianna, M. G. Meekan, A. A. Rogers, M. E. Kragt, J. M. Alin, and J. S. Zimmerhackel, "Shark-diving tourism as a financing mechanism for shark conservation strategies in Malaysia," Mar Policy, vol. 94, pp. 220-226, Aug. 2018.

[70] Y. Swimmer et al., "Sea Turtle Bycatch Mitigation in U.S. Longline Fisheries," Front Mar Sci, vol. 4, no. AUG, p. 260, Aug. 2017.

[71] D. A. Croll et al., "Vulnerabilities and fisheries impacts: the uncertain future of manta and devil rays," Aquat Conserv Mar Freshw Ecosyst, vol. 26, no. 3, pp. 562-575, 2016.

[72] R. C. Anderson, M. S. Adam, A. M. Kitchen-Wheeler, and G. Stevens, "Extent and economic value of manta ray watching in maldives," Tour Mar Environ, vol. 7, no. 1, pp. 15-27, 2011.

[73] J. Farley, "Ecosystem services: The economics debate," Ecosyst Serv, vol. 1, no. 1, pp. 40-49, Jul. 2012.

[74] J. O. Kenter, T. Hyde, M. Christie, and I. Fazey, "The importance of deliberation in valuing ecosystem services in developing countries-Evidence from the Solomon Islands," Glob Environ Chang, vol. 21, no. 2, pp. 505-521, May 2011.

[75] E. Gilman et al., Robbing Peter to pay Paul: replacing unintended cross-taxa conflicts with intentional tradeoffs by moving from piecemeal to integrated fisheries bycatch management, vol. 29, no. 1. Springer International Publishing, 2019.

[76] Y. Dissou and M. S. Siddiqui, “Can carbon taxes be progressive?," Energy Econ, vol. 42, pp. 88100, Mar. 2014.

[77] S. Engel, S. Pagiola, and S. Wunder, "Designing payments for environmental services in theory and practice: An overview of the issues," Ecol Econ, vol. 65, no. 4, pp. 663-674, 2008.

[78] C. Bene, "Small-scale Fisheries: Assessing their contribution to rural livelihoods in developing countries," Rome, 2006.

[79] W. N. S. Arlidge, D. Squires, J. Alfaro-shigueto, H. Booth, J. C. Mangel, and E. J. Milner-Gulland, "A Mitigation Hierarchy Approach for Managing Sea Turtle Captures in Small-Scale Fisheries," Front Mar Sci, vol. 7, no. February, 2020.

[80] M. Levi, A. Sacks, and T. Tyler, "Conceptualizing Legitimacy, Measuring Legitimating Beliefs," Am Behav Sci, vol. 53, no. 3, pp. 354-375, Nov. 2009.

[81] R. Oyanedel, S. Gelcich, and E. J. Milner-Gulland, "Motivations for (non-)compliance with conservation rules by small-scale resource users," Conserv Lett, Apr. 2020.

[82] F. Pakiding et al., "Community Engagement: An Integral Component of a Multifaceted Conservation Approach for the Transboundary Western Pacific Leatherback," Front Mar Sci, vol. 7, p. 756, Sep. 2020. 
[83] CBD, "Long-term strategic directions to the 2050 vision for biodiversity, approaches to living in harmony with nature and preparation for the post-2020 global biodiversity framework.," in CBD/COP/14/9, 2018.

[84] F. Berkes et al., "Globalization, roving bandits, and marine resources," Science, vol. 311, no. 5767. American Association for the Advancement of Science, pp. 1557-1558, 17-Mar-2006.

[85] N. C. Ban, V. Adams, R. L. Pressey, and J. Hicks, "Promise and problems for estimating management costs of marine protected areas," Conserv Lett, vol. 4, no. 3, pp. 241-252, Jun. 2011.

[86] A. Arias, R. L. Pressey, R. E. Jones, J. G. Álvarez-Romero, and J. E. Cinner, “Optimizing enforcement and compliance in offshore marine protected areas: a case study from Cocos Island, Costa Rica," Oryx, vol. 50, no. 01, pp. 18-26, Jan. 2016.

[87] D. C. Bartholomew, J. C. Mangel, J. Alfaro-Shigueto, S. Pingo, A. Jimenez, and B. J. Godley, "Remote electronic monitoring as a potential alternative to on-board observers in small-scale fisheries," Biol Conserv, vol. 219, pp. 35-45, Mar. 2018.

[88] S. C. Mangi, P. J. Dolder, T. L. Catchpole, D. Rodmell, and N. de Rozarieux, "Approaches to fully documented fisheries: practical issues and stakeholder perceptions," Fish Fish, vol. 16, no. 3, pp. 426-452, Sep. 2015.

[89] L. R. Harper et al., "Prospects and challenges of environmental DNA (eDNA) monitoring in freshwater ponds," Hydrobiologia, vol. 826, no. 1. Springer International Publishing, pp. 25-41, 01 Jan-2019.

[90] T. Russo et al., "All is fish that comes to the net: metabarcoding for rapid fisheries catch assessment," bioRxiv, p. 2020.06.18.159830, Jun. 2020.

[91] D. Cardeñosa, M. J. Gollock, and D. D. Chapman, "Development and application of a novel realtime polymerase chain reaction assay to detect illegal trade of the European eel ( Anguilla anguilla )," Conserv Sci Pract, vol. 1, no. 5, p. e39, 2019.

[92] V. F. Griffiths, J. W. Bull, J. Baker, and E. J. Milner-Gulland, "No net loss for people and biodiversity," Conserv Biol, vol. 33, no. 1, pp. 76-87, Feb. 2019.

[93] E. J. Milner-Gulland et al., "Translating the terrestrial mitigation hierarchy to marine megafauna by-catch,” Fish Fish, vol. 19, no. 3, pp. 547-561, 2018.

[94] MFMR, "REPUBLIC OF NAMIBIA MINISTRY OF FISHERIES AND MARINE RESOURCES Annual Report 2012 - 2013," Windhoek, Namibia, 2013.

[95] J. N. Sanchirico, D. Holland, K. Quigley, and M. Fina, "Catch-quota balancing in multispecies individual fishing quotas," Mar Policy, vol. 30, no. 6, pp. 767-785, Nov. 2006.

[96] S. Walker and R. Townsend, "ECONOMIC ANALYSIS OF NEW ZEALAND'S DEEMED VALUE SYSTEM Scott Walker, Ministry of Fisheries," in IIFET 2008 Vietnam Proceedings, 2008, pp. 1-11.

[97] J. N. Sanchirico, "Managing Marine Capture Fisheries with Incentive Based Price Instruments," SSRN Electron J, Nov. 2005. 
[98] S. Pascoe, C. Wilcox, and C. J. Donlan, "Biodiversity Offsets: A Cost-Effective Interim Solution to Seabird Bycatch in Fisheries?," PLoS One, vol. 6, no. 10, p. e25762, Oct. 2011.

[99] Z. Mukherjee, "Controlling stochastic externalities with penalty threats: the case of bycatch," Environ Econ Policy Stud, vol. 18, no. 1, pp. 93-113, Jan. 2016.

[100] R. A. Androkovich and K. R. Stollery, "A stochastic dynamic programming model of bycatch control in fisheries," MAR.RESOUR.ECON., vol. 9, no. 1, pp. 19-30, Sep. 1994.

[101] G. E. Herrera, "Stochastic bycatch, informational asymmetry, and discarding," J Environ Econ Manage, vol. 49, no. 3, pp. 463-483, May 2005.

[102] R. Singh and Q. Weninger, "Bioeconomies of scope and the discard problem in multiple-species fisheries," J Environ Econ Manage, vol. 58, no. 1, pp. 72-92, Jul. 2009.

[103] S. Pascoe, T. Cannard, and A. Steven, "Offset payments can reduce environmental impacts of urban development," Environ Sci Policy, vol. 100, no. June, pp. 205-210, 2019.

[104] ISSF, "Progress summary of 2014-15 ISSF funded marine turtle projects," Washington, D.C, 2016.

[105] G. Schouten and P. Glasbergen, "Creating legitimacy in global private governance: The case of the Roundtable on Sustainable Palm Oil,” Ecol Econ, vol. 70, no. 11, pp. 1891-1899, Sep. 2011.

[106] D. Ruysschaert and D. Salles, "The Strategies and Effectiveness of Conservation NGOs in the Global Voluntary Standards: The Case of the Roundtable on Sustainable Palm Oil," in The Anthropology of Conservation NGOs, Springer International Publishing, 2018, pp. 121-149.

[107] Greater Atlantic Regional Fisheries Office, "Right Whales and Entanglements: More on How NOAA Makes Decisions," NOAA Fisheries, 2019. [Online]. Available: https://www.fisheries.noaa.gov/new-england-mid-atlantic/marine-mammal-protection/rightwhales-and-entanglements-more-how-noaa\#tright-whales-and-the-lobster-fishery. [Accessed: 12Oct-2020].

[108] J. B. Jouffray, B. Crona, E. Wassénius, J. Bebbington, and B. Scholtens, "Leverage points in the financial sector for seafood sustainability," Sci Adv, vol. 5, no. 10, p. eaax3324, Oct. 2019.

[109] H. Österblom et al., "Emergence of a global science-business initiative for ocean stewardship," PNAS, 2017.

[110] CDP, "Deforestation-free supply chains: From commitments to action," no. CDP Global Forests Report 2014, p. 21, 2014.

[111] S. Donofrio, P. Rothrock, and J. Leonard, "Supply Change: Tracking Corporate Commitments to Deforestation-Free Supply Chains. 2017,” Washington, DC, 2017.

[112] H. Österblom et al., "Transnational Corporations as 'Keystone Actors' in Marine Ecosystems," 2015.

[113] G. Galland, A. Rogers, and A. Nickson, "Netting billions: a global valuation of tuna," Pew Charitible Trust, no. May, pp. 1-22, 2016.

[114] A. Balmford, P. Gravestock, N. Hockley, C. J. McClean, and C. M. Roberts, "The worldwide costs 
of marine protected areas," Proc Natl Acad Sci U S A, vol. 101, no. 26, pp. 9694-9697, Jun. 2004.

[115] S. Engel and C. Palmer, "Payments for environmental services as an alternative to logging under weak property rights: The case of Indonesia," Ecol Econ, vol. 65, no. 4, pp. 799-809, 2008.

[116] C. Bonham, M. K. Steininger, M. McGreevey, C. Stone, T. M. Wright, and C. A. Cano, "Conservation trust funds, protected area management effectiveness and conservation outcomes: Lessons from the global conservation fund," Parks, vol. 20, no. 2, pp. 89-100, 2014.

[117] A. Angelsen, M. Brockhaus, M. Kanninen, E. Sills, W. D. Sunderlin, and S. Wertz-Kanounnikof, Eds., Realising REDD+: national strategy and policy options. Bogor, Indonesia: CIFOR, 2009.

\section{Figure legends}

Figure 1. Bycatch as an externality. The difference between the market equilibrium and sociallyoptimal quantity of production when there is a negative externality $(\mathrm{MPC}=$ marginal private cost, $\mathrm{MPB}=$ marginal private gain, $\mathrm{MSC}$ = marginal social cost), depicted through: (a) a supply-demand relationship (where $\mathrm{P}_{\mathrm{M}}=$ price at market equilibrium, $\mathrm{P}_{\mathrm{S}}=$ price at social optimum, $\mathrm{Q}_{\mathrm{M}}=$ quantity demanded at market equilibrium, $\mathrm{Q}_{\mathrm{s}}=$ quantity demanded at social optimum) and (b) a figure of fishing operations, where target catch is coloured blue, bycatch is coloured orange and MPC and MSC are captured within the blue and orange circles, respectively.

Figure 2. Biodiversity outcomes under bycatch levies. (a) A typology of different instruments for reducing bycatch, showing the basic logic of double-dividend levies in terms of creating efficient and effective outcomes which can maximise conservation benefits and social welfare (expanding on Segerson (2011), Innes et al. (2015) and Engel et al. (2008) (Q $\mathrm{Q}_{\mathrm{M}}=$ quantity of bycatch under market equilibrium, Qs = socially-optimal quantity of bycatch) (N.B. other types of market-based mechanisms, such as cap-andtrade, are also available but not included in the scope of this paper). Orange bars below the line indicate the net social (conservation) costs of bycatch under the different management regimes, coloured bars above the line indicate the private (economic) benefits to fishing entities under business as usual (BAU, black), direct regulation (grey) and market-based (blue). (b) A schematic of how double-dividend bycatch levies could contribute to no net loss (NNL) and net gain biodiversity targets, with compensatory conservation occurring after bycatch has occurred and biodiversity gains accruing over time.

Figure 3. A schematic of different possible relationships between target catch production and bycatch, and how different levy designs might lead to conservation impact for different situations. Situation A, where bycatch is homogenous and avoidable, could be exemplified by mobulid ray bycatch in purse-seines during spatio-temporal aggregations; situation $\mathrm{B}$, where bycatch is rare avoidable could be exemplified by sawfish bycatch (and on-board handling/release) in demersal trawls; situation $\mathrm{C}$, where bycatch is homogenous, frequent and difficult to avoid could be exemplified by epipelagic requiem shark bycatch in pelagic tuna longlines; situation $\mathrm{D}$, where bycatch is a rate stochastic event, can be exemplified by sperm whale bycatch in drift nets. 
Table 1. An overview of different bycatch levy models, their relative pros and cons, and the situations to which they may be most suited. $(*$ short-term $=$

697 under current levels of technology; technological innovations may alter bycatch-catch ratios in the long-run

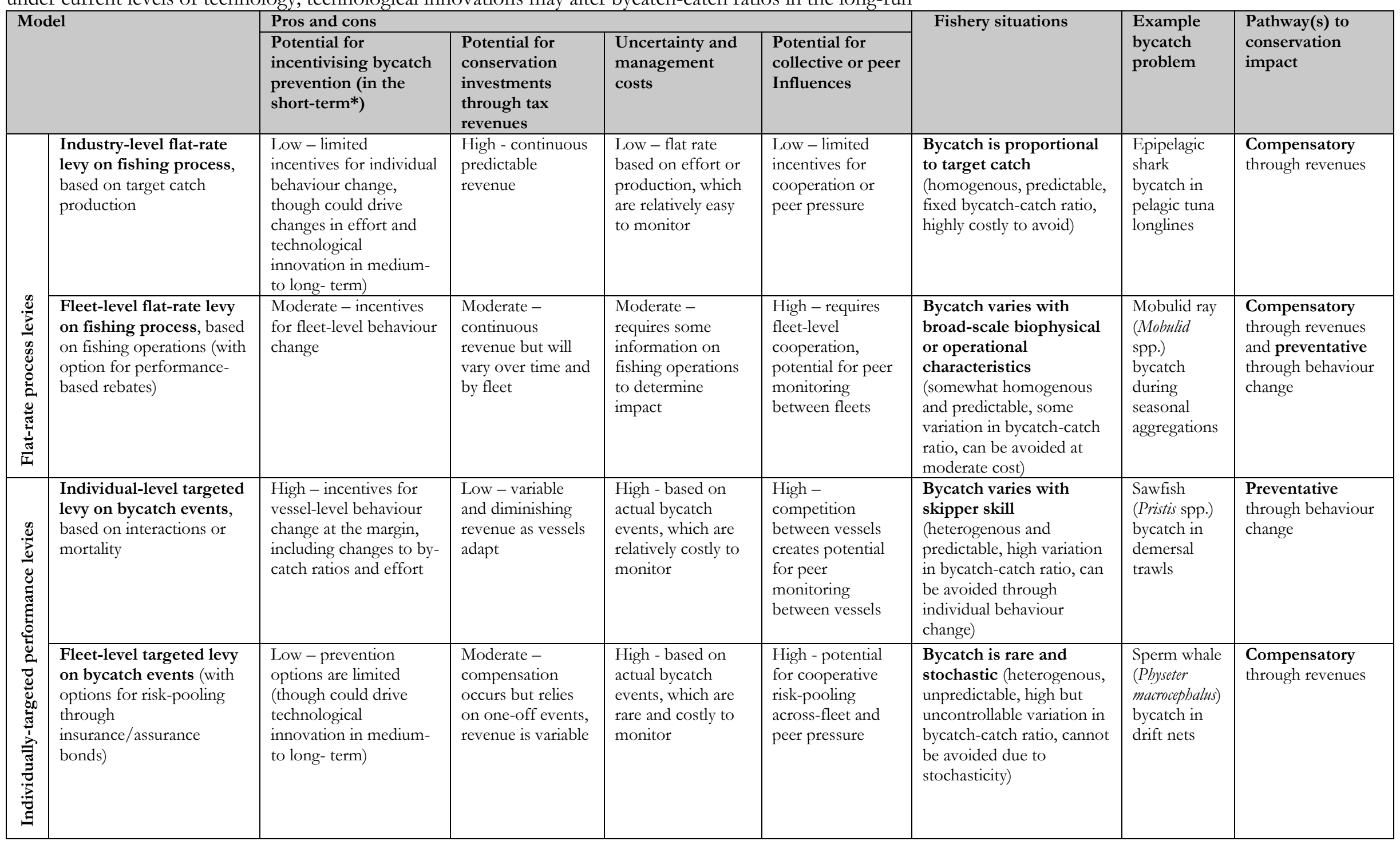


Table 2. Potential scales of distribution and beneficiaries for investing bycatch levy revenues

\begin{tabular}{|c|c|c|c|c|}
\hline $\begin{array}{l}\text { Scale of levy } \\
\text { distribution }\end{array}$ & Payer & $\begin{array}{l}\text { Potential } \\
\text { beneficiaries }\end{array}$ & Suitable situations & $\begin{array}{l}\text { Pathway to } \\
\text { conservation impact }\end{array}$ \\
\hline $\begin{array}{l}\text { Local (e.g. } \\
\text { fleet-level) }\end{array}$ & $\begin{array}{l}\text { Individual } \\
\text { vessels with } \\
\text { high } \\
\text { bycatch } \\
\text { impact }\end{array}$ & $\begin{array}{l}\text { Individual vessels } \\
\text { with low bycatch }\end{array}$ & $\begin{array}{l}\text { Bycatch is heterogenous within } \\
\text { fleets, predictable and } \\
\text { avoidable (i.e. varies within a } \\
\text { fleet based on skipper skill) }\end{array}$ & $\begin{array}{l}\text { Preventative through } \\
\text { incentivising behaviour } \\
\text { change within a fleet. } \\
\text { Could achieve No Net } \\
\text { Loss against } 2020 \\
\text { baselines. }\end{array}$ \\
\hline $\begin{array}{l}\text { National or } \\
\text { sub-national } \\
\text { (e.g. } \\
\text { jurisdiction, } \\
\text { stock or } \\
\text { fisheries } \\
\text { management } \\
\text { area) }\end{array}$ & $\begin{array}{l}\text { Fleets or } \\
\text { companies } \\
\text { with high } \\
\text { bycatch } \\
\text { impact }\end{array}$ & $\begin{array}{l}\text { Fleets or } \\
\text { companies } \\
\text { operating in the } \\
\text { same geography } \\
\text { which } \\
\text { demonstrate low } \\
\text { or reduced } \\
\text { bycatch; } \\
\text { owners/managers } \\
\text { of critical habitat } \\
\text { or parts of the } \\
\text { bycatch affected } \\
\text { stock }\end{array}$ & $\begin{array}{l}\text { Bycatch is homogenous within } \\
\text { fleets, but heterogenous across } \\
\text { fleets (e.g. predictable and } \\
\text { avoidable based on broad-scale } \\
\text { operational and biophysical } \\
\text { characteristics). Could be } \\
\text { progressive by charging } \\
\text { commercial high-revenue fleets } \\
\text { for bycatch, and investing } \\
\text { funds in fleet-wide bycatch } \\
\text { mitigation in small-scale } \\
\text { fisheries, or in performance- } \\
\text { based rewards for improving } \\
\text { the status of by-catch affected } \\
\text { populations. }\end{array}$ & $\begin{array}{l}\text { Preventative through } \\
\text { incentivising behaviour } \\
\text { change across fleets (i.e. } \\
\text { rewards less damaging } \\
\text { fishing practices); } \\
\text { Compensatory } \\
\text { through paying for } \\
\text { habitat or population } \\
\text { conservation. Could } \\
\text { achieve Net Gain } \\
\text { against } 2020 \text { baselines. }\end{array}$ \\
\hline $\begin{array}{l}\text { International } \\
\text { (e.g. between } \\
\text { countries) }\end{array}$ & $\begin{array}{l}\text { Countries } \\
\text { or } \\
\text { companies } \\
\text { with high } \\
\text { bycatch } \\
\text { impact }\end{array}$ & $\begin{array}{l}\text { Fleets or } \\
\text { companies } \\
\text { operating } \\
\text { elsewhere which } \\
\text { demonstrate low } \\
\text { or reduced } \\
\text { bycatch; } \\
\text { owners/managers } \\
\text { of critical habitat } \\
\text { or populations of } \\
\text { bycatch-affected } \\
\text { species elsewhere }\end{array}$ & $\begin{array}{l}\text { Bycatch is homogenous within } \\
\text { fleets, but unavoidable due to } \\
\text { tight coupling with target catch } \\
\text { production; bycatch is } \\
\text { stochastic and unavoidable. } \\
\text { Could be progressive by } \\
\text { charging high-revenue } \\
\text { commercial fleets for their } \\
\text { bycatch in Global North } \\
\text { counties, and investing funds } \\
\text { in bycatch mitigation or } \\
\text { conservation actions to } \\
\text { improve the status of by-catch } \\
\text { affected populations in Global } \\
\text { South countries. }\end{array}$ & $\begin{array}{l}\text { Compensatory } \\
\text { through paying for } \\
\text { habitat or population } \\
\text { conservation [32], or } \\
\text { performance-based } \\
\text { catch mitigation } \\
\text { elsewhere. Could } \\
\text { achieve Net Gain } \\
\text { against } 2020 \text { baselines. }\end{array}$ \\
\hline
\end{tabular}


Table 3. Examples of real-world applications of bycatch levies

\begin{tabular}{|c|c|c|c|c|c|c|c|c|c|c|}
\hline Fishery/entity & $\begin{array}{l}\text { Target } \\
\text { species }\end{array}$ & Fishing area & $\begin{array}{l}\text { Bycaught } \\
\text { species }\end{array}$ & $\begin{array}{l}\text { Management } \\
\text { objective }\end{array}$ & Mechanism & $\begin{array}{l}\text { Preventative } \\
\text { measures }\end{array}$ & $\begin{array}{l}\text { Compliance } \\
\text { management }\end{array}$ & $\begin{array}{l}\text { Amt levied } \\
\text { per annum }\end{array}$ & $\begin{array}{l}\text { Scale of tax } \\
\text { distribution }\end{array}$ & Refs \\
\hline $\begin{array}{l}\text { International } \\
\text { Seafood } \\
\text { Sustainability } \\
\text { Foundation } \\
\text { (ISSF), US-based } \\
\text { tuna processors }\end{array}$ & Tuna & Worldwide & Sea turtles & $\begin{array}{l}\text { Yield revenue to } \\
\text { finance } \\
\text { conservation, } \\
\text { reputational } \\
\text { (enhance } \\
\text { environmental } \\
\text { standing in } \\
\text { consumer markets) }\end{array}$ & $\begin{array}{l}\text { Voluntary, } \\
\text { industry-led } \\
\text { - flat-rate tax } \\
\text { per ton of } \\
\text { longline- } \\
\text { caught tuna. }\end{array}$ & $\begin{array}{l}\text { Gear standards/ } \\
\text { modifications, } \\
\text { live release } \\
\text { protocols }\end{array}$ & $\begin{array}{l}\mathrm{N} / \mathrm{A}-\text { flat rate } \\
\text { payment for } \\
\text { voluntary } \\
\text { participating } \\
\text { companies }\end{array}$ & $\begin{array}{l}\text { US\$100,000 } \\
(2016)\end{array}$ & $\begin{array}{l}\text { International - } \\
\text { finances sea turtle } \\
\text { conservation in } \\
\text { nesting habitats and } \\
\text { small-scale fisheries } \\
\text { in Pacific, Indian } \\
\text { and Atlantic } \\
\text { Oceans. }\end{array}$ & $\begin{array}{l}{[52],} \\
{[82],} \\
{[104]}\end{array}$ \\
\hline $\begin{array}{l}\text { Namibian large } \\
\text { pelagic fishery } \\
\text { (longline) }\end{array}$ & $\begin{array}{l}\text { Swordfish, } \\
\text { blue \& } \\
\text { short-fin } \\
\text { mako sharks }\end{array}$ & $\begin{array}{l}\text { Pelagic } \\
\text { offshore. } \\
\text { South Atlantic } \\
\text { Ocean } \\
\text { (Namibian } \\
\text { EEZ and high } \\
\text { seas). }\end{array}$ & $\begin{array}{l}\text { Tuna, thresher } \\
\text { shark, marlin }\end{array}$ & $\begin{array}{l}\text { To prevent } \\
\text { unlicensed catch of } \\
\text { species that are not } \\
\text { included in quota. }\end{array}$ & $\begin{array}{l}\text { Mandatory } \\
\text { bycatch fee } \\
\text { levied for } \\
\text { non-target } \\
\text { species }\end{array}$ & Unclear & Unclear & $\begin{array}{l}\text { US\$400,000 } \\
(2012 / 3)\end{array}$ & $\begin{array}{l}\text { Unclear, likely } \\
\text { fiscally-neutral }\end{array}$ & $\begin{array}{l}{[33],} \\
{[94]}\end{array}$ \\
\hline $\begin{array}{l}\text { New Zealand } \\
\text { multi-species } \\
\text { commercial } \\
\text { fisheries }\end{array}$ & $\begin{array}{l}\text { Multi- } \\
\text { species }\end{array}$ & $\begin{array}{l}\text { Several quota } \\
\text { management } \\
\text { areas within } \\
\text { EEZ. }\end{array}$ & $\begin{array}{l}93 \text { species } \\
\text { included in } \\
\text { quota } \\
\text { management } \\
\text { system }\end{array}$ & $\begin{array}{l}\text { Reduce discards of } \\
\text { over-quota } \\
\text { Bycatch (i.e. } \\
\text { management- } \\
\text { induced discards) }\end{array}$ & $\begin{array}{l}\text { Mandatory } \\
\text { individual } \\
\text { bycatch } \\
\text { quotas, with } \\
\text { bycatch levy } \\
\text { through } \\
\text { deemed- } \\
\text { value system. }\end{array}$ & Quota & $\begin{array}{l}\text { Dual reporting } \\
\text { system for } \\
\text { fishers and } \\
\text { purchasers to } \\
\text { fill forms } \\
\text { matching } \\
\text { catches to } \\
\text { permits. Some } \\
\text { observer } \\
\text { coverage }\end{array}$ & Unclear & $\begin{array}{l}\text { Unclear, likely } \\
\text { fiscally-neutral }\end{array}$ & $\begin{array}{l}{[33],} \\
{[95],} \\
{[96]}\end{array}$ \\
\hline $\begin{array}{l}\text { California } \\
\text { swordfish (drift } \\
\text { gillnet) / the } \\
\text { Federation of } \\
\text { Independent } \\
\text { Seafood } \\
\text { Harvesters } \\
\text { (FISH) }\end{array}$ & Swordfish & $\begin{array}{l}\text { Pelagic } \\
\text { offshore. } \\
\text { Pacific Ocean } \\
\text { (Along East } \\
\text { coast, between } \\
\text { state waters } \\
\text { and EEZ). }\end{array}$ & $\begin{array}{l}\text { Sea turtles } \\
\text { leatherback } \\
\text { (Dermochelys } \\
\text { coriacea) }\end{array}$ & & $\begin{array}{l}\text { Voluntary, } \\
\text { industry-led - } \\
\text { donations, } \\
\text { not linked to } \\
\text { level of } \\
\text { bycatch }\end{array}$ & $\begin{array}{l}\text { Spatio-temporal } \\
\text { closures }\end{array}$ & $\begin{array}{l}\text { N/A voluntary } \\
\text { donations }\end{array}$ & $\begin{array}{l}\text { US71,000 } \\
(2004)\end{array}$ & $\begin{array}{l}\text { International - } \\
\text { Invested in turtle } \\
\text { nesting habitat } \\
\text { conservation in } \\
\text { Baja California, } \\
\text { Mexico. Impact } \\
\text { unclear. }\end{array}$ & $\begin{array}{l}{[51],} \\
{[52]}\end{array}$ \\
\hline
\end{tabular}



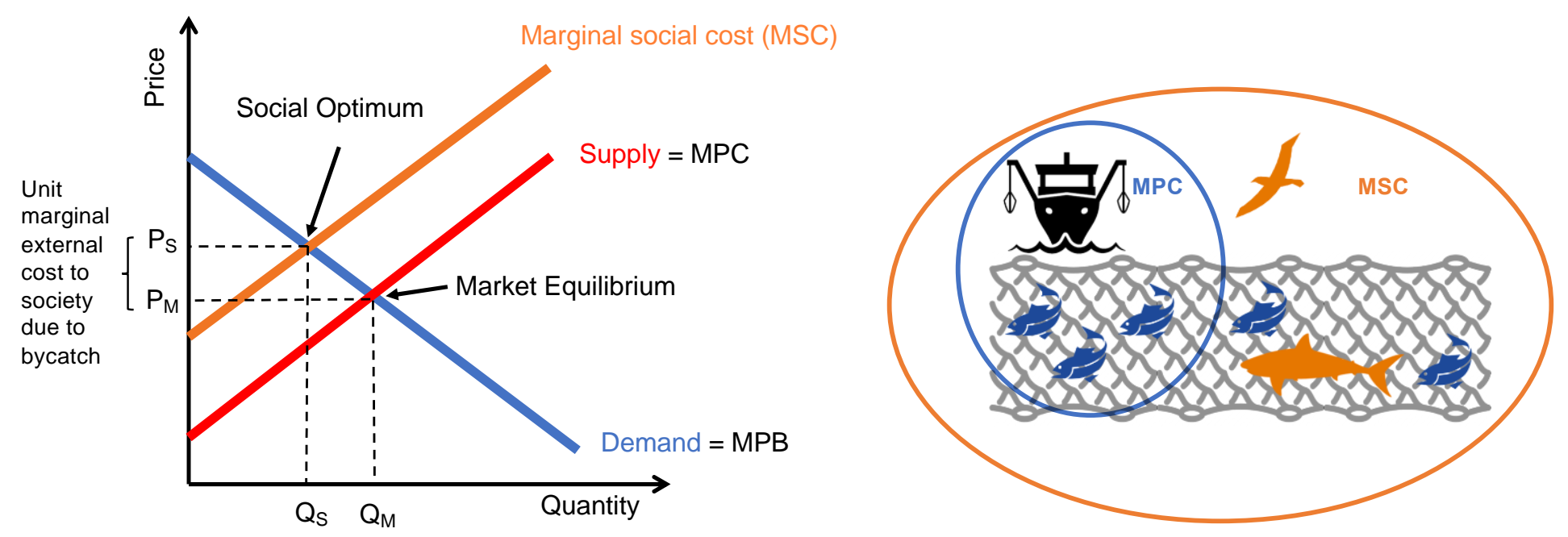


\section{BAU}
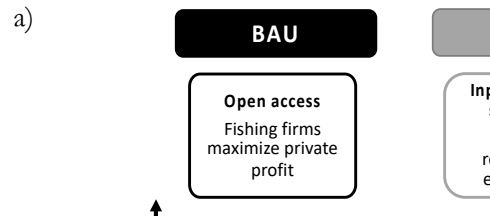

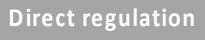

Input-oriented
standards
e.g. gear

restrictions,
effort limits

ted
s
nits

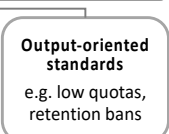

e.g. low quotas,
retention bans

\section{Market-based}

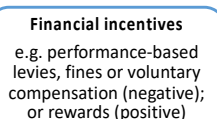

compensation (negative)

or rewards (positive)

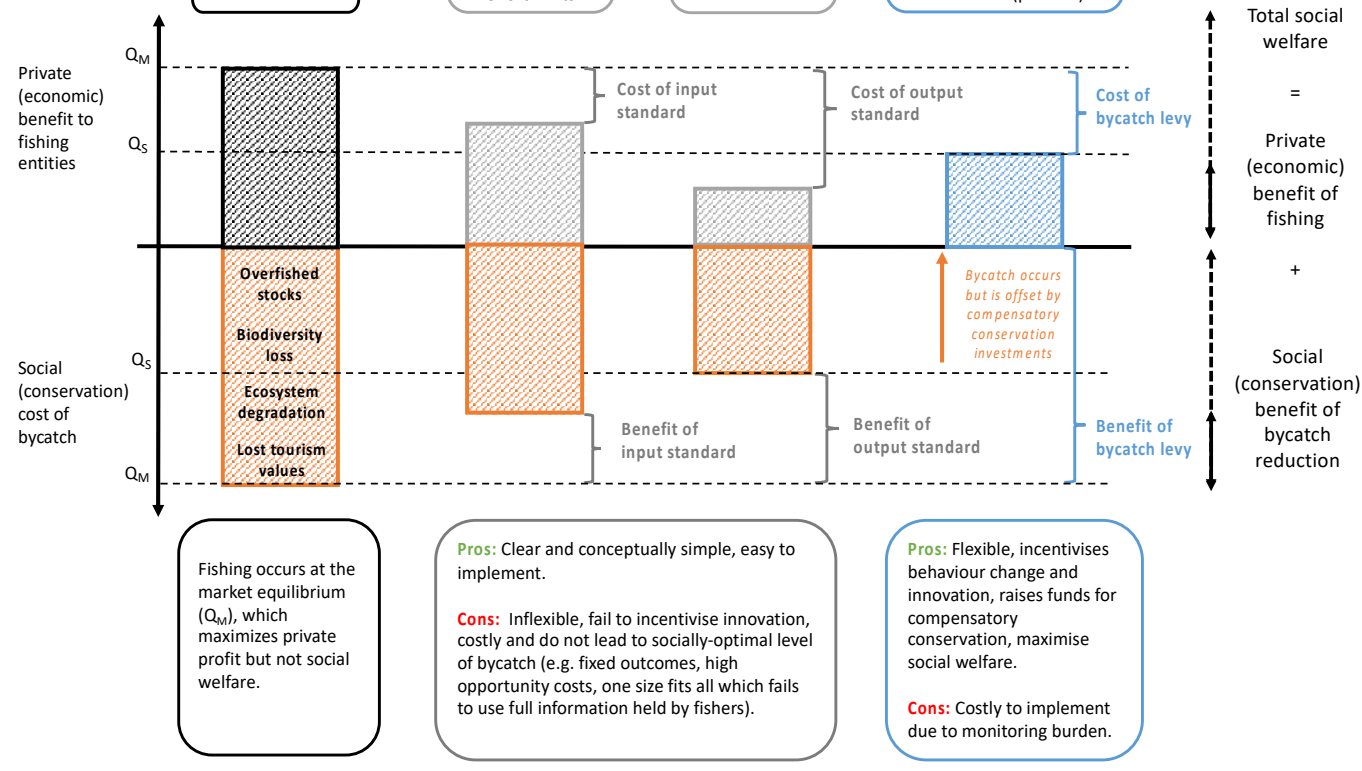

b)

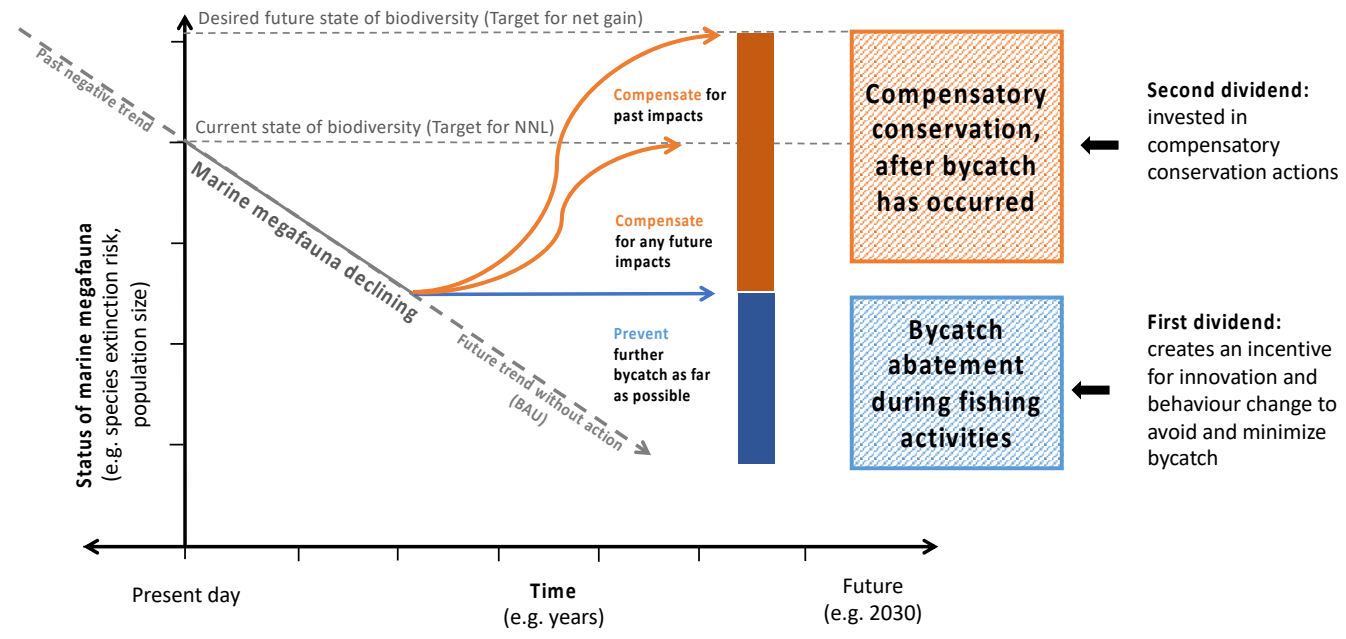




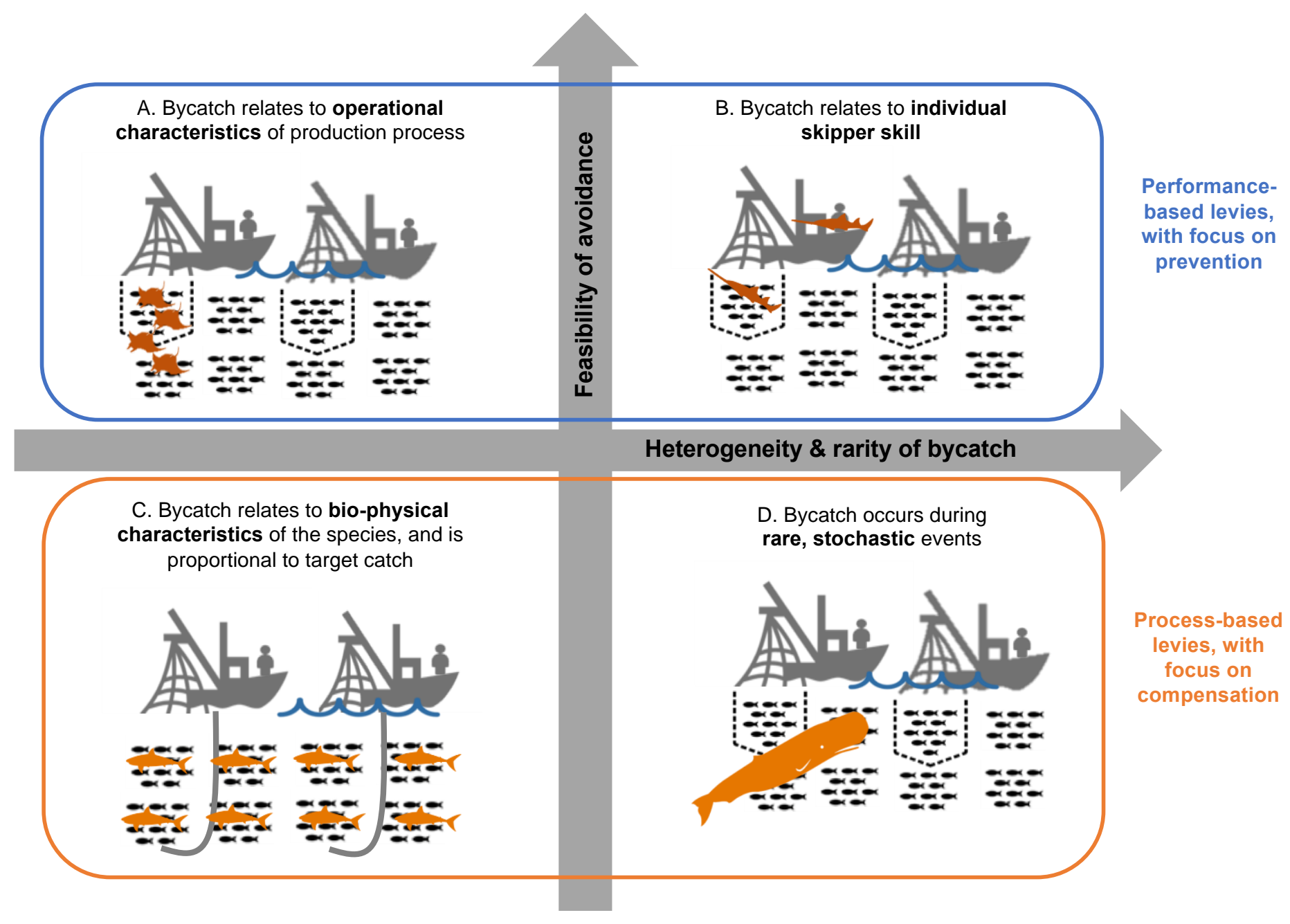

